\title{
Development progress monitoring system in Engineering Procurement Construction (EPC) company with Earn Value Analysis (EVA) approach based on web mobile
}

\author{
Rhadityo Shakti Budiman ${ }^{1, *}$ and I Ketut Gunarta ${ }^{1}$ \\ ${ }^{1}$ Management Engineering, Industrial Engineering Department, 60119 Surabaya, Indonesia
}

\begin{abstract}
At the time, development of technology and system information provide an idea in project management information system. One of industrial which growing up in Indonesia is Engineering Procurement and Construction (EPC), in this case required a system to facilitate between all stakeholders to improve their performance. Progress report on the project that was created approach using earn value analysis (EVA) system which considered cost and schedule of work as well as a productivity performance index of workers. In addition, project progress was formed by comparing between plans and realization of work which has projected since of the beginning of the project. The result on the system was provides information of progress every time through on the dashboard page input by the user. The first step of making a report on the system, started which input the project name and then step over to make the detailed work in each department or discipline in project. The data obtained were then processed by the project control team to provide information of progress project status against the top management. The establishment of information system can be stored and accessed online by all user who have been classified in the system. That information can be integrated between the top management to take a decision against the ongoing project.
\end{abstract}

\section{Introduction}

Innovation and technological progress in the field of industrial engineering in the development of the present impact of development in the country to facilitate the needs of the community, because it is in the present era we often see projects in large and small scale. To create a strong construction industry towards global competition is one of the objectives of a nation in carrying out sustainable development [1], This is influenced by increased investment in transport and energy infrastructure and construction-related industries in the mining sector, highly visible construction industry developed rapidly within the last ten years. In order to increase economic growth through infrastructure development in Indonesia, the Government made efforts to accelerate projects that are

* Corresponding author: srhadityo@yahoo.com 
considered strategy and has high urgency can be realized within a short time. By mid-2016 to early 2017 have been carried out evaluation and selection of strategic projects and mechanisms for accelerating development. The results of the evaluation and selection set forth in the Presidential Decree No. 58 Year 2017 regarding the amendment of Presidential Decree Nox3 [2]

One of the employment contract scheme to implement development projects related industries, infrastructure, and energy sectors can be done with the design build contract scheme or commonly known as the engineering procurement construction (EPC). Implementation of the project also needed a system of control at the company's resources in order to remain well preserved and executives can pay attention to the project is running properly. Control of the project commonly referred to as project management. Project management is the integration of inter-workplace, scheduling and financing in a measure that aims to identify the exact problems and adjust the project plan ahead. [3]

In the development of the Project Monitoring Information System in the present era is needed to help the project owner to exercise control over a work in progress and ensure that the work is in accordance with the planned schedule. This occurs because the dominant factors affecting the failure of a project is the lack of a control system in the implementation of the work. [4], To determine the success of future projects, we need a warning system capable of providing an indication of an issue to the potential subject of money, time or quality. Information technology is one tool that can be used to present data on ongoing projects accurately and in real time.

\section{Literature Review}

\subsection{Project Management}

Project is a temporary activity undertaken to create a unique product and service [5]. Unique is meant here is to form a product or service desired different from previous projects. The project also has a temporary nature that has the initial and final restrictions in the implementation time [6]. In the course of the project can also be defined as an activity undertaken to achieve certain objectives and targets within which is limited with the resources and time required to complete the work [7]. While Project Management of Knowledge is a temporary activity undertaken to create a product, service or unique results [5]. Project activity will stop if the goal has been reached with the agreed result. While project management is the process of planning, organizing, leading and relying on the resources of financial companies, labor, materials and equipment to achieve the goals have been determined.

\subsection{Engineering Procurement Construction (EPC)}

EPC is a project management concept responsible for designing and designing Engineering, procurement of materials and equipment or Procurement and construction work. [8] explains that each EPC has its own characteristics. EPC projects are often found in largescale projects or commonly known as special projects such as industrial development, refineries, fertilizer plants that require large funds and reach thousands of activities in a single project. High-scale projects are also indispensable for a cutting-edge technology to work from procurement to construction. In Indonesia, EPC business is regulated in Regulation of Minister of Industry Number: 54 / M-IND / PER / 3/2012. 


\section{a. Earn Value Analysis (EVA)}

Earn value analysis (EVA) or commonly known as Earn Value Management (EVM) is a method to measure and mengkomonikasikan progress of work performance of a project. EVM for 40 years has explored actual schedule and cost calculations for each achievement compared to project planning [9] This method provides project performance status information for a specific time period and provides the cost prediction information required for the completion of all jobs based on performance indicators when reporting.

By using Earn Value method can know the performance of activities that are being done and can increase the effectiveness in project achievement activities. Approach to the concept of earn value is to calculate the amount of cost according to the budget in accordance with the work that has been implemented. When viewed from the amount of work completed, this concept regulates the size of the completed work unit at a time when judged by the amount of budget provided for the project [10].

\section{b. System Development Life Cycle (SDLC)}

System Development Life Cycle is a software development lifecycle that consists of several important stages in building software in terms of its development. The system development process passes through several stages of system planning until the system is implemented, operated and maintained. System planning is established to address critical and nonresolvable issues. The main stages of the system development cycle consist of system planning stages, system analysis, system design, system selection, system implementation and system maintenance [11]

\section{Research Methodology}

This research methodology is used as a reference of researchers so that it can run systematically and in accordance with the research framework. Research stages include literature review, system development, data processing phase, analysis and data interpretation phase, conclusion drawing stage, and implementation stage of writing or research implementation schedule. At the research stage, the data collection process is done with primary data and secondary data. Primary data collection is done through observation and interview. While secondary data collection comes from supporting journals and documents from related companies and other stakeholders.

\section{Result and Discussion}

The approach that has been done to know the condition of the project is quite a lot done as developed by Firdaus and Yulia Hastuti discussing a formation of construction project cost control system using ear value management method integrated with MACES-CP (Most Accurate Cost Estimation for Construction Project ) with the object of observation of construction company in Indonesia. Meanwhile, other approaches made by Aljibouri using Leading Parameter approach, Activity Based Ratio and Earn Value Analysis to create a control system on the project that aims to make cost effective by modeling the system. In another study was developed by Anastasia Mishakova that combines two methods of project progress control with PERT and Earn Value Analysis (EVA) with the object of observation on construction project in Russia. From several journals that become refrensi, implementation of Earn Value Analysis system formation to an EPC construction company still not much done, the last research that developed process of Earn Value Analysis based 
web done by C.J. Torrecilla-Salinas with a focus on the technique of incorporating System Development Life Cycle Agile with Web Enginering.

The approach method used in system design is structured approach method with information system design tool using Data Flow Diagram (DFD) and database design using Entity Relationship Diagram (ERD). Work Breakdown Structure (WBS) is also performed on the company as the object of research, in addition to analyzing the Organization Breakdown Structure (OBS) of the company. This is the figure of intersection between Work Breakdown Structure (WBS) and Organization Breakdown Structure (OBS) to show that cost account that have been made to this system.

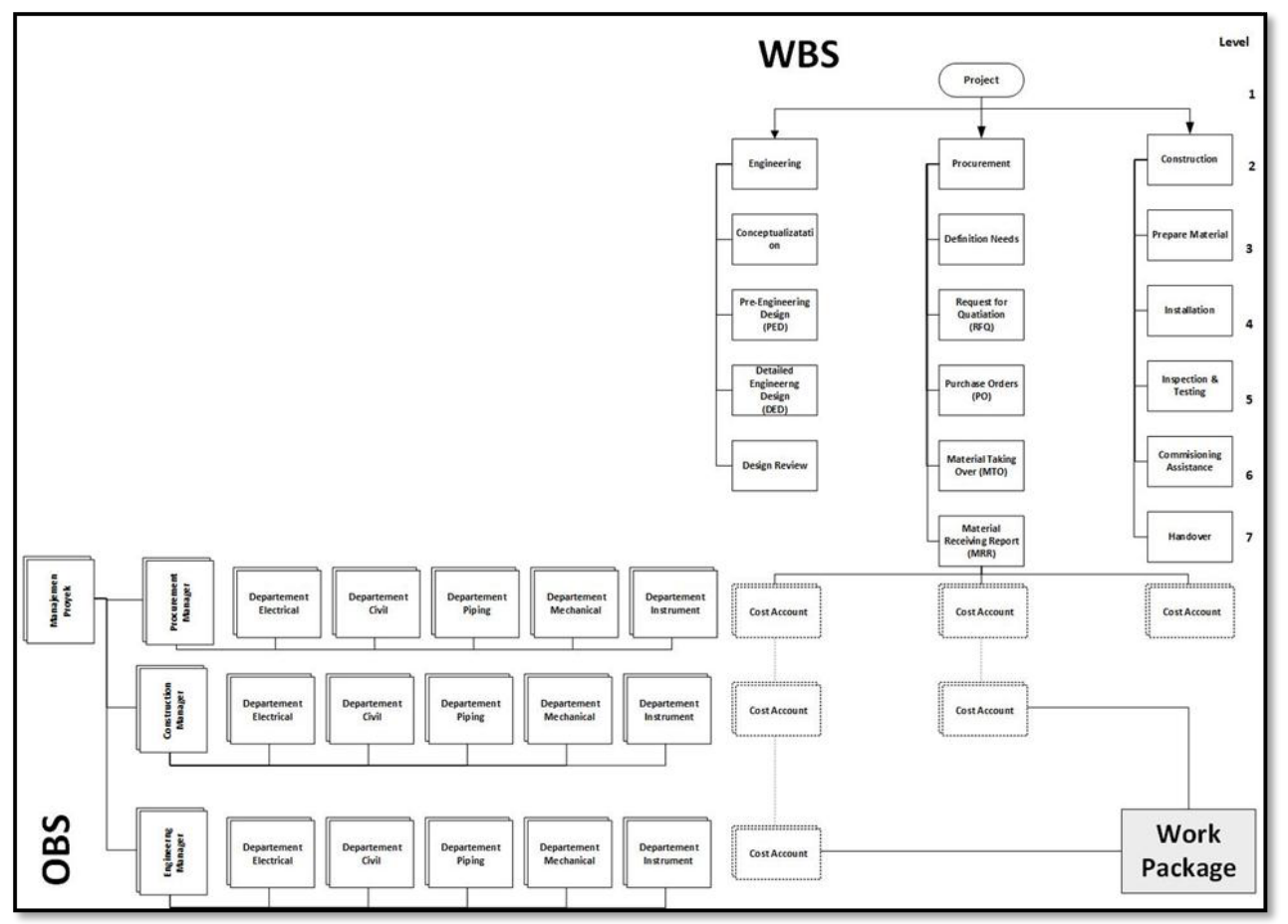

Fig. 1. Intersection Between WBS \& OBS

Design stage is a process to create a physical model as the initial representation of system design followed by the implementation of the system to know a system has been running in accordance with the initial planning by conducting a phased test that is verification and validation test.. At this stage the system has been designed and analyzed will be designed about the physical design that aims to present the specifications that have been established in the previous stage. Stages of system design consist of database design, user interface design, and algorithm design.

Entity Relationship Diagram (ERD) is the first step of the establishment of websites and databases that have a relationship between one table with another, or so-called Relational Database Management Systems (RDMS) so that later data is entered data stored and integrated between one department and the other. The main purpose in establishing the database system is to know and analyze the progress of various projects that have been implemented so that will provide information output for management.

Interface design aims to assist users in using the system so as not to feel difficulty in its use. An important design interface is created to support the work to make it easier and 
faster. In the menu design hierarchy is used to describe the main menu and sub-menus contained in the system created.

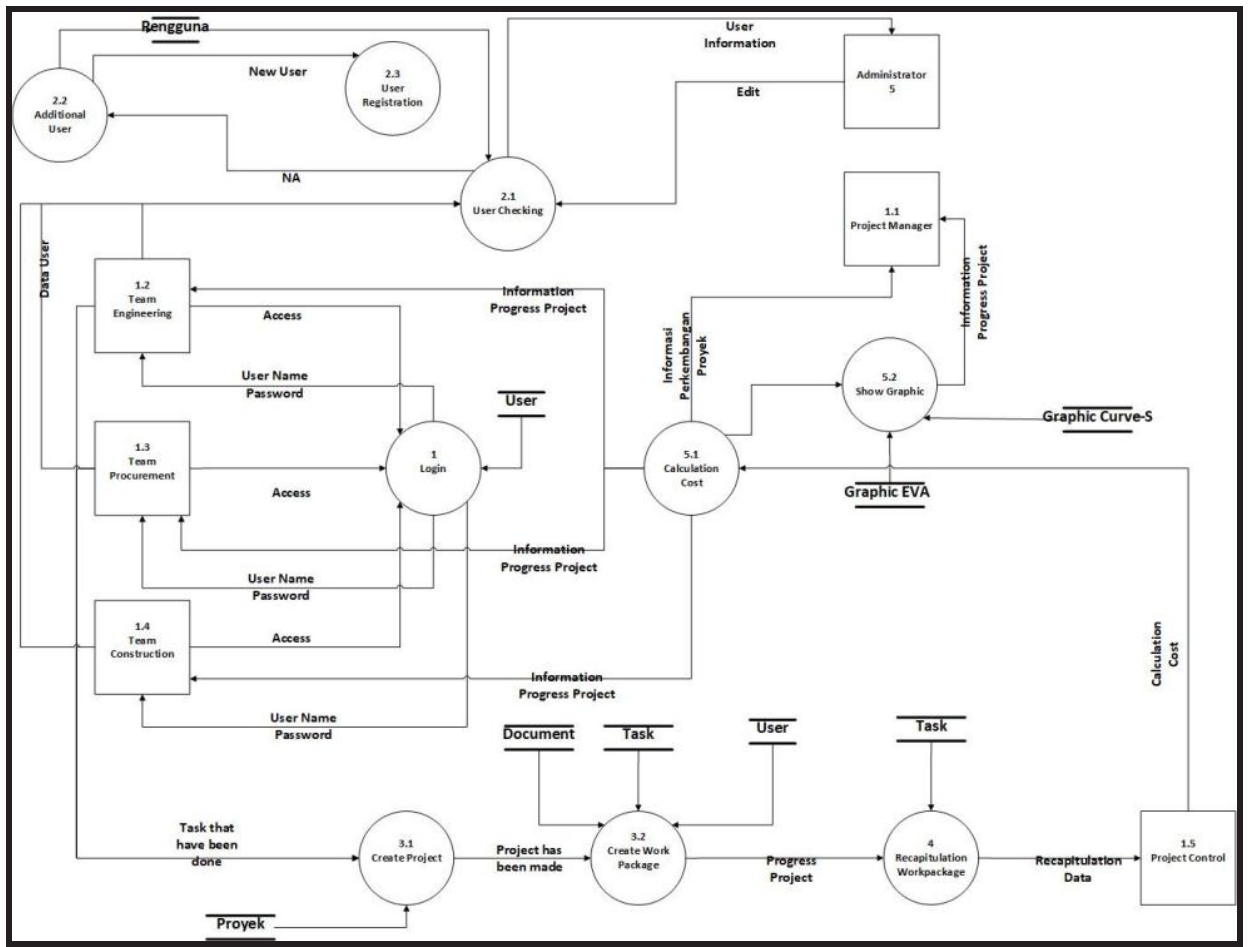

Fig. 2. Design Flow Diagram

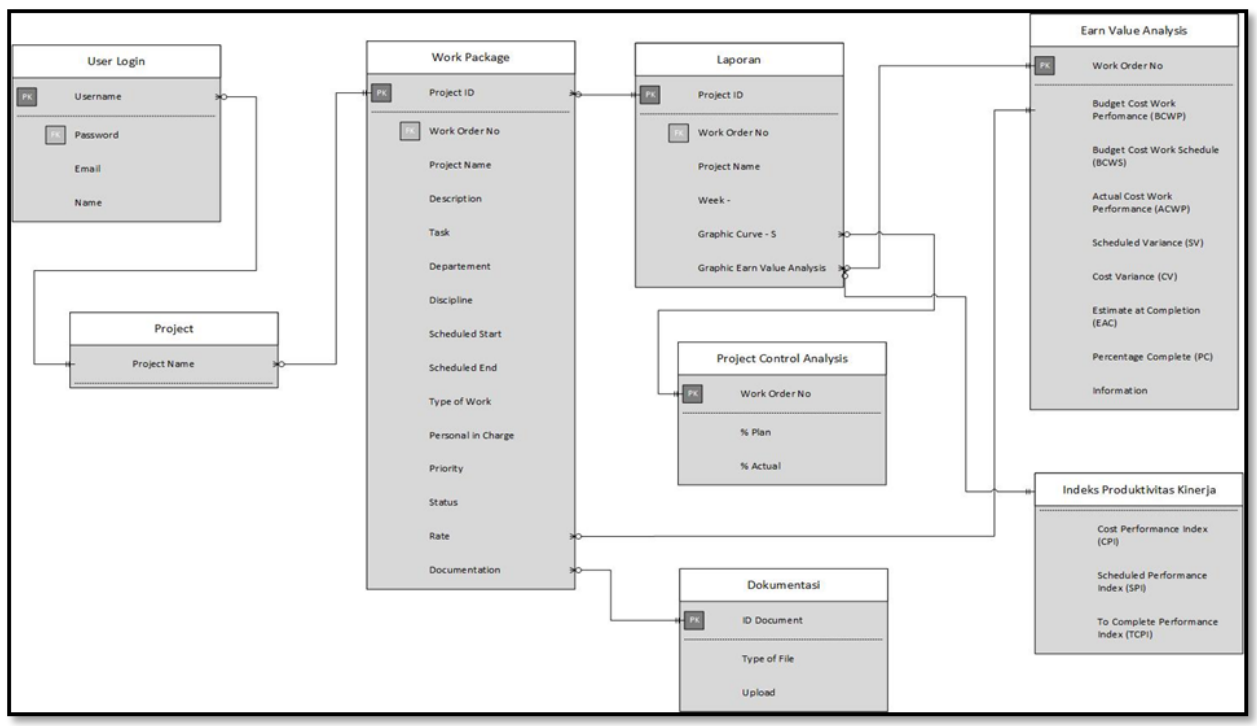

Fig. 3. Entity Relationship Diagram (ERD) 


\section{Conclusion}

Development progress monitoring system in Engineering Procurement Construction (EPC) company with Earn Value Analysis (EVA) approach based on web mobile, could get the conclusion:

1. On the results of the test the design of the website has met from the input and output needs factor, and meet the needs of users based on the Organizational Breakdown Structure (OBS) that exist in the EPC, so that later information output given can answer the needs of users of the website is a graph curve -s and earn value analysis (EVA) graphs in real time.

2. In this information system has formed a database server for the progress of the project by using the programming language MySQL and PHP, which can be accessed by the user so that the information provided can be known in real time by other users, especially for top management to be able to know the progress of the project ongoing.

3. The results of website design quality assessment using Webqual 4.0 method indicates that the ease of accessing the website is the highest score of $84 \%$, so if categorized as including excellent quality. Then the instrument that has the lowest quality value is on the communication instrument between users who have a percentage of $70 \%$ and included in either category. So that later this instrument has a top priority as an instrument that needs to be improved.

\section{References}

1. Mustow. Engineering Sustainability 11-21 (2006)

2. KPPIP. KPPIP. Retrieved from KPPIP: https://kppip.go.id/proyek-strategis-nasional/

3. Gowan. (2006). Earned Value Management in a Data Warehouse Project. Information \& Management Computer Security (2016)

4. A. Irmawanto, C. U. Seminar Nasional Manajemen Teknologi (2011)

5. Project Management Body of Knowledge (2004)

6. D. S. A. Peerapong. Journal of American Association of Cost Engineering (2006)

7. Asiyanto. Construction Project Cost Management (2007)

8. E. A. Schram. In 14th Annual Conference of the International Group for Lean Construction (2003)

9. Alvarado. A compilation of resources on knowledge cities and knowledge-based development (2004)

10. R. M. Siregar. Algoritma Pengendalian Proyek Automation Systems Menggunakan Teknik PERT/CPM \& EVM di Industri Minyak dan Gas Bumi. Jakarta: Universitas Indonesia (2010)

11. H. M. M. A. Jogiyanto. Analisis dan Desain Sistem Informasi . Yogyakarta: Penerbit Andi (2005) 